\title{
Indoor Air Quality Assessments in Educational Facilities in Saudi Arabia: A Systematic Review
}

\author{
Areej Alama \\ Faculty of Design and Architecture, Dar \\ Al-Hekma University, Jeddah, Saudi Arabia \\ areejalama87@gmail.com
}

\author{
Mostafa Sabbagh \\ Faculty of Architecture and Planning, King \\ Abdulaziz University, Jeddah, Saudi Arabia
}

Mjsabbagh@kau.edu.sa

(Received 1/11/2020; accepted for publication 21/3/2021.)

\begin{abstract}
Indoor Air Quality (IAQ) assessments conducted in classrooms in hot arid regions differ greatly from cases found in the general literature due to variations in sociocultural context, climatic conditions, building design, and operation. This paper aims to create a systematic review on IAQ of educational buildings in the Kingdom of Saudi Arabia (KSA) within the past 25 years, identify pollution risks, and indicate gaps in investigations. The review covers a collection of IAQ indices from subjective investigations, experimental studies, simulation work, physical environmental measurements, and statistical analysis from multi-disciplinary fields to introduce a holistic overview. This review is significant since investigations for such context with complete reliance on mechanical air-conditioning (AC), are limited in number and level of details. Using PRISMA guidelines, 17 original studies were found to fit the review criterion; some were unique in terms of examined variables. Among the reviewed studies, classroom $\mathrm{CO} 2$ concentrations and some of the measured indoor air pollutants were significantly higher than the values recommended by reference standards. Serious health risks and bacterial contaminations were associated with poor AC systems and inefficient ventilation. Implementation of practical guidelines is recommended to mitigate indoor environmental issues in classrooms and reduce their physical and psychological impact on occupants .
\end{abstract}

Keywords: Indoor Air Quality; indoor air pollutant; CO2 concentration; particulate matter; heavy metals; contamination; thermal comfort; educational facility

Practical Implications: This systematic review objectively exposes risks and challenges that may be presiding in the indoor environment of classrooms in Saudi Arabia and the surrounding region with similar climatic conditions. It shows the limited amount of national investigations found in the literature. This review also clearly identifies gaps in investigations and monitoring and signifies the urgency and direction of actions needed by local stakeholders. A collective effort and multidisciplinary interventions should be considered to further examine and enhance classrooms' environmental conditions for students to thrive and succeed.

\section{Introduction}

Indoor Air Quality (IAQ) is one of the main physical parameters ofIndoor EnvironmentalQuality (IEQ) that impact occupants' wellbeing and comfort. The Environmental Protection Agency (EPA) defines good IAQ as good control of indoor airborne pollutants, adequate outdoor air supply and distribution, and maintenance of acceptable levels of indoor relative humidity $(\mathrm{RH})$ and air temperature as they affect the indoor contamination (EPA, last updated 2020). Factors affecting the degree of IAQ include pollutants from biological sources, chemicals from commercial products, and particulate matter (EPA, 1989). Pollutants may include mold and fungi growth, airborne viruses and bacteria, 
asbestos from insulation, radon gas, lead released from building materials and finishes, heavy metal particles, and Volatile Organic Compounds (VOCs) that are harmful chemicals emitted from products and processes (WHO, 2004). Additional sources of pollutants may include occupants' bio effluent that is also partially influenced by their activity level and metabolic rate, and outdoor pollutants that may infiltrate the building (Mujan et al., 2019; Panagiotaras et al., 2014). Takigawa et al. (2009) stated that the Sick Building Syndrome (SBS) is impacted mainly by high levels of Indoor Air Pollutants (IAP) specifically the biological contaminants as VOC and Formaldehyde. Decreasing these concentrations enhances IAQ, and reduces symptoms of SBS, such as dizziness and headaches.

Students and staff spend the school hours mostly confined in mechanically air-conditioned (AC) buildings that are normally densely-occupied. This, along with the nature of school activities, lead to accumulated biological gases and bacteria, and high levels of pollutants. Contaminated indoor air can have negative impact on students' learning abilities, performance and attention, and can result in harmful health respiratory and asthma issues (Cleary et al., 2017; Satish et al., 2011; WHO, 2004). This is further reflected on students' short-term health and risks of infectious diseases impacting their attendance. Serious neurological or cancerous problems were also reported by the World Health Organization (WHO, 2004). Globally, numerous studies investigated and assessed IAQ in educational spaces. Studies were mostly done in Australia, the United States, as well as Finland, United Kingdom, Sweden, and other European nations, and countries in East Asia as Japan and China (Bluyssen et al., 2020). In the Arab countries, where the climatic and cultural conditions may differ, IAQ assessments are rare. This was found to be also true to national stage in Kingdome of Saudi Arabia (KSA), where climate is characterized to be hot-arid (average temperature range of 37 to $45{ }^{\circ} \mathrm{C}$ ), with scarce precipitation (Alrashed \& Asif, 2015) and high level of dust and seasonal sandstorms (Al-Rehaili, 2002). This kind of harsh climatic characteristic led to complete reliance on mechanical ventilation and AC (ElSharkawy, 2014) and smaller envelope openings. Windows would be designed for daylight transmittance over ventilation (Al-Khateeb et al.,
2017). Making assessments for such context is well needed to identify areas of risks and potential improvements, and particularly important as existing assessments are limited in number and level of details (Al-Khatri, 2020; Alzahrani, 2018; El-Sharkawy, 2014; Al-Rehaili, 2002).

This paper aims to review available studies investigating classrooms' IAQ and the level of pollution risks existing in educational facilities in KSA. A collection of IAQ indices and variables are used to help introduce a cohesive overview. IAQ patterns and potential risks are discussed to help characterizing IAP levels, developing recommendations and implementing corrective measures to guide national development of healthy educational spaces for students to learn, succeed, and thrive.

\section{Methodology}

\subsection{Literature Search Strategy}

This paper followed the Preferred Reporting Items for Systematic Reviews and Meta-Analysis (PRISMA), consisting of four phases represented in a flow-diagram; these are: identification, screening, eligibility, and included. The study initiated a search in peer-reviewed literature in all languages. Search records were screened, and eligibility criteria applied, reducing the number of included articles. PRISMA is recommended (Zhu et al., 2020; Bower et al., 2019; Moher et al., 2009) as it improves the reporting quality of the systematic review and provides a better understanding of the literature selection process while ensuring transparency and avoiding bias.

The literature search was performed on June 30, 2020. All related records published up to the search date were included. Keywords were identified to limit the searched items. Topics covered different indices related to IAQ, such as the IAP, their concentrations, contamination risks, thermal conditions affecting occupant comfort, and technical tools developed for assessment purposes. Keywords used for this search were: "Saudi Arabia" and "classroom or schools" and "indoor air quality or thermal comfort or air pollutants or contamination".

A range of databases were incorporated in the initial search, then were excluded during the title and abstract screening as the appearing results were not relevant. Eligible searched databases included; 
Web of Science, ScienceDirect, Scopus, Springer, the Saudi Digital Library, and Google Scholar. Two weeks prior to final submitting the systematic review paper for editorial approval, an updated search was performed in the specified databases in order to identify any newly published studies related to the scope of this review. At this stage, no additional records meeting the selection criteria were found.

\subsection{Inclusion and Exclusion Filtration Criteria}

A filtration criterion was developed to refine the selection of reviewed literature. Studies included in this review are the ones investigating IAQ and thermal conditions in educational facilities in KSA. They were limited to assessment of classrooms with similar building use as schools, colleges, and universities. Articles excluded from this review include studies not reporting quantitative data on IAQ, studies focusing solely on external environmental measurements, studies focusing on evaluating IEQ parameters other than IAQ and thermal conditions, and studies conducted in educational spaces other than classrooms (e.g. laboratory, teachers' offices).

The inclusion search followed a process to identify, select, and categorize the literature; these steps are:

1. Preliminary process started by screening the titles and abstracts of all retrieved records to determine which studies are eligible for full-text assessment.

2. Full-text articles were screened and evaluated, then the ones meeting the inclusion criteria were selected.

3. After reviewing and selecting the initial group of eligible full-text literature articles, their bibliographies were screened for additional relevant literature.

4. Selected full-text articles were categorized based on title relevance or field of study, for reviewing purposes.

5. The authors of the selected articles were contacted inquiring for additional published articles or valuable unpublished data with a similar scope.

6. The final step involved searching for any available gray literature on the topic, including unpublished research material and reports

\section{Results}

\subsection{PRISMA Flow Process}

After mining the databases, a total of 203 literature items were identified as an initial stage of PRISMA process (Figure 1). Several database filters were applied in order to eliminate unrelated publications.

A total of 56 literature items were selected after title and abstract screening, and the removal of:

- the duplicated items

- articles with unrelated topics

- studies conducted outside KSA

- and items without full-text available

The remaining records were subject to full-text assessment. A total of 21 articles met the eligibility stage; while the other 35 items were excluded for the following reasons:

- the study is not reporting quantitative data on IAQ in KSA,

- the study was focused solely on external environmental measurements,

- the study was conducted in non-classroom / non-educational spaces.

A final refinement was conducted, and four articles, where the same authorship team had published multiple papers from one study (Alzahrani, 2018; Alzahrani et al., 2020; Al-Sulaihi et al., 2015; Al-Sulaihi et al., 2015; Ahmed et al., 2017; Ahmed et al., 2017; Ahmed et al., 2018), were excluded due to duplicated findings. Eventually, a total of 17 studies were included in the review.

\subsection{Studies Characteristics}

The PRISMA process concluded to 17 studies published between 1999 and 2020 (Figure 2). The papers were conducted in three main Saudi cities: Riyadh (in the central region), Jeddah (in the West coastal region), and Dammam (in the East region). Almost half of the studies focused on school settings, while the other half were conducted in facilities for higher education (universities/colleges). Most of the studies conducted assessment of IAQ (Hassan and Abdallal, 2011; Alsubaie, 2014; Al-Sulaihi et al., 2015; Al-Mijalli, 2016; Ahmed et al., 2017; Alzahrani, 2018; Alghamdi et al., 2019; Alghamdi et al., 2020, Al-Hebshi et al., 2020; Al-Khatri et al., 2020), while few investigated the indoor and outdoor measures to compare findings and relationships between the ambient measures and indoor environmental values (Al-Rehaili, 1999; 


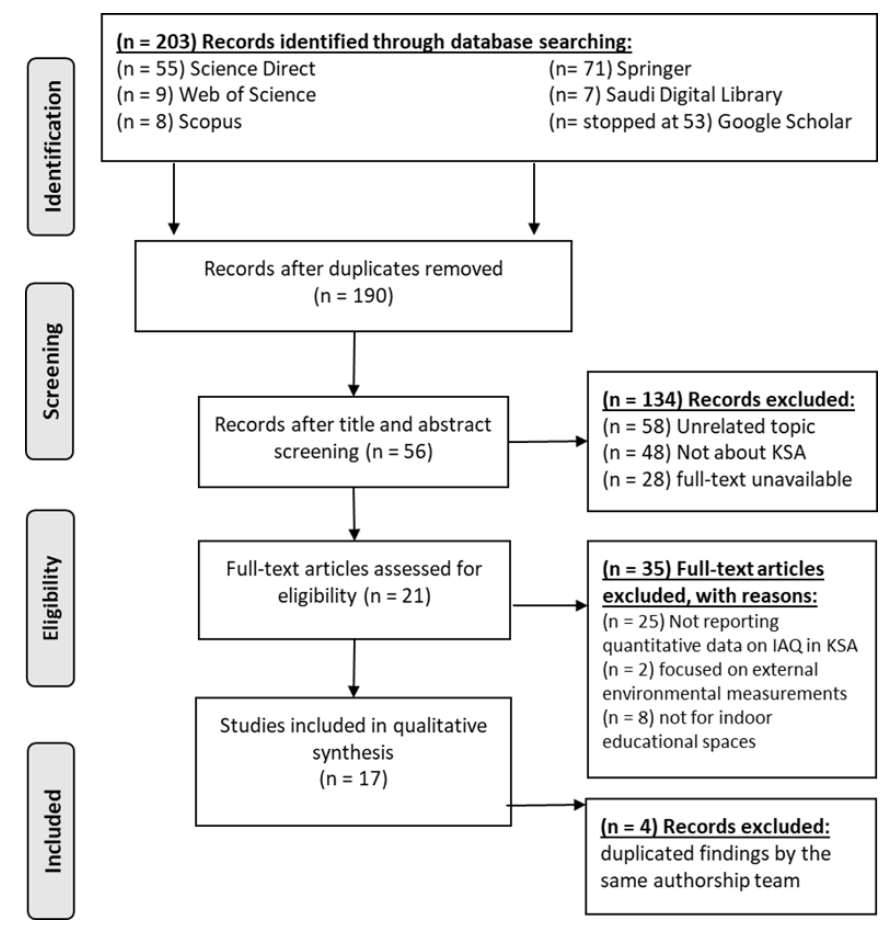

Figure 1. Article selection process following PRISMA guidelines

Al-Rehaili, 2002; Alghamdi, 2013; El-Sharkawy, 2014; Al-Khateeb et al., 2017; Sebiany et al., 2018).

While most of the reviewed studies addressed classroom IAQ through objective field measurements of environmental conditions, few of them looked into the subjective side of their study in order to evaluate the thermal sensations of occupants of examined classrooms, the impact of environmental conditions on participants abilities and skills, their socio-economic background, and medical history (Ahmed et al., 2017; Sebiany et al., 2018; Alzahrani, 2018; Al-Hebshi et al., 2020; Al-Khatri et al., 2020). Questionnaire surveys, ASHRAE thermal scale, and cognitive tests were various forms used for the subjective assessment. One study investigated the relationship between participants' gender and their thermal sensations and adaptive actions in high schools (Al-Khatri et al., 2020). Table 1 lists the selected literature.

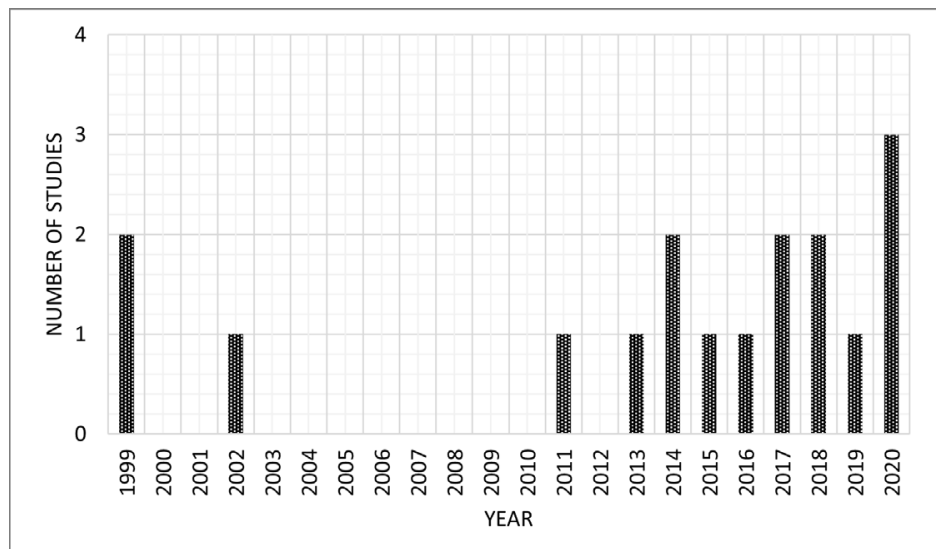

Figure 2. Number of IAQ publications in KSA over time 
Table 1. Literature items selected for review analysis.

\begin{tabular}{|c|c|c|c|c|}
\hline \multicolumn{5}{|c|}{ Selected literature items for review } \\
\hline $\begin{array}{l}\text { Item } \\
\text { number }\end{array}$ & Article title & Reference & Published in & Search engine \\
\hline 1 & $\begin{array}{l}\text { Outdoor-indoor air quality in } \\
\text { Riyadh: } \mathrm{NO}, \mathrm{NO}_{2} \text {, and } \mathrm{O}_{3}\end{array}$ & (Al-Rehaili, 1999) & Ecology and the Environment & Google Scholar \\
\hline 2 & $\begin{array}{l}\text { Outdoor-indoor air quality in } \\
\text { Riyadh: Particulate Matter, } \mathrm{Pb} \text { and } \\
\mathrm{CO}\end{array}$ & (Al-Rehaili, 1999) & The Built Environment & Google Scholar \\
\hline 3 & $\begin{array}{l}\text { Outdoor-indoor air quality in } \\
\text { Riyadh: } \mathrm{SO}_{2}, \mathrm{NH}_{3} \text {, and } \mathrm{HCHO}\end{array}$ & (Al-Rehaili, 2002) & $\begin{array}{l}\text { Environmental Monitoring and } \\
\text { Assessment }\end{array}$ & Springer \\
\hline 4 & $\begin{array}{l}\text { Populations and distribution of } \\
\text { filamentous fungi and bacteria in } \\
\text { some educational buildings in } \\
\text { Dammam, eastern KSA }\end{array}$ & $\begin{array}{l}\text { (Hassan and Al- } \\
\text { Abdalall, 2011) }\end{array}$ & $\begin{array}{l}\text { Journal of Food, Agriculture \& } \\
\text { Environment }\end{array}$ & $\begin{array}{l}\text { Web of Science \& } \\
\text { Scopus }\end{array}$ \\
\hline 5 & $\begin{array}{l}\text { Indoor/ Outdoor Particulate Matter } \\
\text { Concentrations at Some Elementary } \\
\text { Schools in Jeddah, KSA }\end{array}$ & (Alghamdi, 2013) & Met., Env. \& Arid Land Agric. Sci. & $\begin{array}{l}\text { The Saudi Digital } \\
\text { Library }\end{array}$ \\
\hline 6 & $\begin{array}{l}\text { Study the IAQ level inside } \\
\text { governmental elementary schools of } \\
\text { Dammam City in KSA }\end{array}$ & (El-Sharkawy, 2014) & $\begin{array}{l}\text { International Journal of } \\
\text { Environmental Health Engineering }\end{array}$ & Google Scholar \\
\hline 7 & $\begin{array}{l}\text { Indoor air ventilation in primary } \\
\text { schools in eastern province, KSA }\end{array}$ & (Alsubaie, 2014) & $\begin{array}{l}\text { International Journal of Current } \\
\text { Research }\end{array}$ & Google Schol \\
\hline 8 & $\begin{array}{l}\text { Assessing IEQ of educational } \\
\text { buildings using BIM }\end{array}$ & $\begin{array}{l}\text { (Al-Sulaihi et al., } \\
\text { 2015) }\end{array}$ & $\begin{array}{l}\text { Journal of Environmental Science } \\
\text { and Engineering }\end{array}$ & Google Scholar \\
\hline 9 & $\begin{array}{l}\text { Bacterial Contamination of Indoor } \\
\text { Air in Schools of Riyadh, KSA }\end{array}$ & (Al-Mijalli, 2016) & Air \& Water Borne Diseases & Google Scholar \\
\hline 10 & $\begin{array}{l}\text { Seasonal variation of indoor radon } \\
\text { concentration in a desert climate }\end{array}$ & $\begin{array}{l}\text { (Al-Khateeb et al., } \\
\text { 2017) }\end{array}$ & Applied Radiation and Isotopes & ScienceDirect \\
\hline 11 & $\begin{array}{l}\text { The effect of indoor temperature and } \\
\mathrm{CO}_{2} \text { levels on cognitive performance } \\
\text { of adult females in a university } \\
\text { building in KSA }\end{array}$ & (Ahmed et al., 2017) & Energy Procedia & ScienceDirect \\
\hline 12 & $\begin{array}{l}\text { Association between air pollutants } \\
\text { and anthropometric measurements of } \\
\text { boys in primary schools in } \\
\text { Dammam, eastern KSA }\end{array}$ & (Sebiany et al., 2018) & $\begin{array}{l}\text { Journal of Family and Community } \\
\text { Medicine }\end{array}$ & Web of Science \\
\hline 13 & $\begin{array}{l}\text { Developing a model for assessing the } \\
\text { effect of physical IEQ on teachers' } \\
\text { performance in Saudi educational } \\
\text { buildings }\end{array}$ & (Alzahrani, 2018) & $\begin{array}{l}\text { WIRE, University } \\
\text { Wolverhampton }\end{array}$ & Google Scholar \\
\hline 14 & $\begin{array}{l}\text { Risk Assessment and Implications of } \\
\text { School children Exposure to } \\
\text { Classroom Heavy Metals Particles in } \\
\text { Jeddah, KSA }\end{array}$ & $\begin{array}{l}\text { (Alghamdi et al., } \\
\text { 2019) }\end{array}$ & $\begin{array}{l}\text { International Journal of } \\
\text { Environmental Research and Public } \\
\text { Health }\end{array}$ & $\begin{array}{l}\text { Web of Science } \\
\& \\
\text { Scopus }\end{array}$ \\
\hline 15 & $\begin{array}{l}\text { Classroom Dust-Bound Polycyclic } \\
\text { Aromatic Hydrocarbons in Jeddah } \\
\text { Primary Schools, KSA: Level, } \\
\text { Characteristics and Health Risk } \\
\text { Assessment }\end{array}$ & $\begin{array}{l}\text { (Alghamdi et al., } \\
\text { 2020) }\end{array}$ & $\begin{array}{l}\text { International Journal of } \\
\text { Environmental Research and Public } \\
\text { Health }\end{array}$ & Scopus \\
\hline 16 & $\begin{array}{l}\text { Improving thermal sensation in } \\
\text { classrooms with respect to draft } \\
\text { avoidance by optimizing the } \\
\text { mechanical air supply method }\end{array}$ & $\begin{array}{l}\text { (Al-Hebshi et al., } \\
\text { 2020) }\end{array}$ & $\begin{array}{l}86^{\text {th }} \text { Research World International } \\
\text { Conference }\end{array}$ & Google Scholar \\
\hline 17 & $\begin{array}{l}\text { Exploring thermal comfort } \\
\text { experience and } \\
\text { opportunities of female and male } \\
\text { high school students }\end{array}$ & $\begin{array}{l}\text { (Al-Khatri et al., } \\
\text { 2020) }\end{array}$ & Journal of Building Engineering & ScienceDirect \\
\hline
\end{tabular}




\section{Discussion}

Considerably few studies met the search criteria. Those studies conducted their investigation from various angles. Some reported actual assessment data or measured values of the indoor educational spaces while others approached IAQ from the angle of health and microbial risks. Developing methods to assess and enhance IAQ and thermal conditions was the objective of some of the selected reviewed articles. The following sections analyze these studies.

\subsection{CO2 Concentration Levels and IAP in Classroom Setting}

Al-Rehaili's study is one of the earliest in KSA addressing IAQ in buildings (Amoatey et al., 2018). The evaluation included 32 buildings in Riyadh city between 1992 and 1994 of different types, and included one educational facility (Al-Rehaili, 2002). A total of ten air pollutants and other environmental parameters were monitored and measured for four days during summer, and four days during winter season. Environmental data collected included outdoor temperature, RH, solar radiation, and wind speed and direction, as well as indoor air temperature and RH.

The investigation showed that sulfur dioxide (SO2) and ammonia (NH3) recorded values exceeding the standard recommended levels for both indoor and outdoor, with indoor being worse during winter season. formaldehyde (HCHO) level was high at some sites with outdoor being higher (Al-Rehaili, 2002). Similarly, the indoor and outdoor Total Suspended Particles (TSP), Lead ( $\mathrm{Pb}$ ), nitrates (NO) and nitrogen dioxide (NO2) were higher than recommended values at most examined locations. However, carbon monoxide (CO) measurement showed acceptable levels, except for few sites located in congested heavy-traffic areas, with summer values being higher than winter (Al-Rehaili, 1999). Ozon (O3) results revealed acceptable levels in all examined locations (Al-Rehaili, 1999) (Table 2).

El-Sharkawy's (2014) investigation involved assessing IAQ and levels of IAP in elementary public schools in Dammam city. Variables reported include street traffic, classroom location on floor plan, type of public school examined, window and classroom areas, occupancy, and ventilation rate. A total of 16 public schools were examined; 12 of them were formal school buildings (constructed to be purposed as a school), and the other four schools were rentals (repurposed to become a school).

Table 2. Summary of indoor and outdoor air pollutants at the examined sites reported in studies by Al-Rehaili in comparison with recommended standard value limits

\begin{tabular}{|c|c|c|c|c|}
\hline Air Pollutant & $\begin{array}{l}\text { Range of indoor } \\
\text { concentration }\end{array}$ & $\begin{array}{l}\text { Range of outdoor } \\
\text { concentrations }\end{array}$ & $\begin{array}{c}\text { Recommended } \\
\text { values }\end{array}$ & Reference \\
\hline $\mathrm{SO}_{2}$ & $\begin{array}{l}0.001 \text { to } 1.5 \mathrm{ppm} \\
\text { Mean: } 0.46 \mathrm{ppm}\end{array}$ & $\begin{array}{l}0.043 \text { to } 1.49 \mathrm{ppm} \\
\text { Mean: } 0.42 \mathrm{ppm}\end{array}$ & $0.28 \mathrm{ppm}$ & *MEPA \\
\hline $\mathbf{N H}_{3}$ & $\begin{array}{l}0.472 \text { to } 2.91 \mathrm{ppm} \\
\text { Mean: } 1.46 \mathrm{ppm}\end{array}$ & $\begin{array}{c}0.337 \text { to } 3.937 \mathrm{ppm} \\
\text { Mean: } 2.92 \mathrm{ppm}\end{array}$ & $0.72 \mathrm{ppm}$ & **ASHRAE Standard \\
\hline НСНО & $\begin{array}{l}0.0 \text { to } 0.076 \mathrm{ppm} \\
\text { Mean: } 0.022\end{array}$ & $\begin{array}{l}0.0 \text { to } 0.129 \mathrm{ppm} \\
\text { Mean: } 0.029 \mathrm{ppm}\end{array}$ & $0.1 \mathrm{ppm}$ & ASHRAE Standard \\
\hline TSP & $\begin{array}{c}6 \text { to } 478 \mu \mathrm{g} / \mathrm{m}^{3} \\
\text { Mean: } 68.9 \mu \mathrm{g} / \mathrm{m}^{3}\end{array}$ & $\begin{array}{c}64 \text { to } 1892 \mu \mathrm{g} / \mathrm{m}^{3} \\
\text { Mean: } 307.25 \mu \mathrm{g} / \mathrm{m}^{3}\end{array}$ & $\begin{array}{l}150 \mu \mathrm{g} / \mathrm{m}^{3} \\
340 \mu \mathrm{g} / \mathrm{m}^{3}\end{array}$ & $\begin{array}{c}* * * \text { WHO } \\
\text { Saudi Standard }\end{array}$ \\
\hline $\mathbf{P b}$ & $\begin{array}{c}0.01 \text { to } 2.13 \mu \mathrm{g} / \mathrm{m}^{3} \\
\text { Mean: } 0.7 \mu \mathrm{g} / \mathrm{m}^{3}\end{array}$ & $\begin{array}{l}0.13 \text { to } 6.19 \mu \mathrm{g} / \mathrm{m}^{3} \\
\text { Mean: } 8.803 \mu \mathrm{g} / \mathrm{m}^{3}\end{array}$ & $1.5 \mu \mathrm{g} / \mathrm{m}^{3}$ & $* * * *$ USEPA \\
\hline NO & $\begin{array}{l}0.073 \text { to } 2.82 \mathrm{ppm} \\
\text { Mean: } 0.88 \mathrm{ppm}\end{array}$ & $\begin{array}{l}0.077 \text { to } 4.14 \mathrm{ppm} \\
\text { Mean: } 1.103 \mathrm{ppm}\end{array}$ & $0.82 \mathrm{ppm}$ & ASHRAE Standard \\
\hline $\mathrm{NO}_{2}$ & $\begin{array}{l}0.023 \text { to } 0.609 \mathrm{ppm} \\
\text { Mean: } 0.171 \mathrm{ppm}\end{array}$ & $\begin{array}{l}0.001 \text { to } 0.859 \mathrm{ppm} \\
\text { Mean: } 0.267 \mathrm{ppm}\end{array}$ & $0.053 \mathrm{ppm}$ & MEPA \\
\hline $\mathrm{CO}$ & $\begin{array}{l}0.0 \text { to } 116 \mathrm{ppm} \\
\text { Mean: } 4.02 \mathrm{ppm}\end{array}$ & $\begin{array}{c}0.0 \text { to } 59 \mathrm{ppm} \\
\text { Mean: } 2.76 \mathrm{ppm}\end{array}$ & $35 \mathrm{ppm}$ & Saudi Standard \\
\hline $\mathbf{O}_{3}$ & $\begin{array}{c}1.0 \text { to } 38 \mathrm{ppb} \\
\text { Mean: } 6.92 \mathrm{ppb}\end{array}$ & $\begin{array}{c}4.01044 \mathrm{ppb} \\
\text { Mean: } 19.92 \mathrm{ppb}\end{array}$ & $\begin{array}{l}0.15 \mathrm{ppb} \\
0.05 \mathrm{ppb}\end{array}$ & $\begin{array}{c}\text { MEPA } \\
\text { ASHRAE Standard }\end{array}$ \\
\hline
\end{tabular}

*MEPA: Meteorological and Environmental Protection Administration

**ASHRAE: The American Society of Heating, Refrigerating and Air-Conditioning Engineers

$* * *$ WHO: World Health Organization

$* * * *$ USEPA: United States Environmental Protection Agency 
Sample size selection were proportional to school types. Measurements included the indoor thermal conditions (air temperature and $\mathrm{RH}$ ), and levels of air pollutants (including TSP, $\mathrm{CO}, \mathrm{CO} 2, \mathrm{NO} 2, \mathrm{SO} 2$, and Benzene); recorded using personal air sampler. Measurements were compared to national and international Air Quality Guidelines (AQGs) recommended by the WHO. In each examined school, four classrooms were selected for measurement sampling, and a fifth point outside to record the ambient measures. For IAP other than TSP, measurements were conducted at two periods during school time; from 08:00 to 09:00 AM, and after recess; with 15 to 30 minutes recordings at each period. TSP levels were measured using a two-hour continuous measurement for one period. IAP concentration were generally higher in formal public schools compared with the rented buildings. This is due to differences in the site location, design of each type, and number of occupants being higher in public schools. Concentrations in classrooms located on the ground floor were higher than levels in the ones located at upper floors due to the dispersion process. No correlation between $\mathrm{CO} 2$ levels and the total volume of windows, indicating reliance on mechanical AC systems. This concurs to a conclusion found by Alsubaie (2014), that windows are kept closed most of the time due to KSA harsh climate.

El-Sharkawy (2014) also found that CO2 levels were higher than recommended by WHO and AQGs, in all examined classrooms. Similarly, concentrations of $\mathrm{SO} 2$ and Benzene were over the standard values in $50 \%$ of the investigated classrooms. The average levels of TSP, NO2, and $\mathrm{CO}$ were lower than maximum allowed by standards. Indoor air temperatures were higher than the values recommended by ASHRAE Standard-55 $\left(26-26.5^{\circ} \mathrm{C}\right.$ during the first period, rising in the late morning to $27-27.4{ }^{\circ} \mathrm{C}$ ) (ASHRAE Standard-55, 2017), which negatively impacted students' perceived thermal comfort. Testing the effect of street traffic on pollutants' levels reflected pollutants' concentrations higher for schools located on moderate traffic street compared to low traffic. However, mean $\mathrm{CO} 2$ concentrations were found to be influenced mainly by indoor occupant rather than outdoor traffic conditions.

Alsubaie compared $\mathrm{CO} 2$ concentration levels in classrooms at two public school typologies; formal public and rented. A total of 36 elementary schools were examined in the Eastern province, KSA; 26 formal public, and 10 rented buildings. In each school, four classrooms were selected randomly for spot measurements. Sampling of $\mathrm{CO} 2$ was conducted at two periods during school hours. Results indicate that mean $\mathrm{CO} 2$ concentration levels in almost $90 \%$ of the examined classrooms were higher than the $1,000 \mathrm{ppm}$ recommended by ASHRAE Standard 62.1 (2013). CO2 levels in rented schools were higher than formal schools, in both measurement periods, with noon period reporting higher levels than morning Both El-Sharkawy and Alsubaie's studies (Table 3 ), traced relatively poor IAQ to inadequate ventilation, high occupant-density and activity

Table 2. Summary of indoor and outdoor air pollutants at the examined sites reported in studies by Al-Rehaili in comparison with recommended standard value limits

\begin{tabular}{|c|c|c|c|c|c|c|c|}
\hline Study & $\begin{array}{c}\text { Data } \\
\text { collection } \\
\text { date }\end{array}$ & Subject & $\begin{array}{c}\text { Measureme } \\
\text { nt method }\end{array}$ & Pollutant & $\begin{array}{c}\text { Avg } \\
\text { Concentrations at } \\
\text { Formal Public } \\
\text { Schools }\end{array}$ & $\begin{array}{c}\text { Avg } \\
\text { Concentrations at } \\
\text { Rented Public } \\
\text { Schools }\end{array}$ & $\begin{array}{c}\text { Occupant } \\
\text { Count }\end{array}$ \\
\hline $\begin{array}{c}\text { (El- } \\
\text { Sharkawy, } \\
\text { 2014) }\end{array}$ & $\begin{array}{c}\text { Estimated } \\
\text { year of } \\
\text { study: } \\
\text { Academic } \\
\text { year of } 2013\end{array}$ & $\begin{array}{l}16 \text { public schools: } \\
\text { - } 12 \text { formal } \\
\text { schools } \\
\text { (governmental } \\
\text { constructed) } \\
\text { - } 4 \text { rented schools }\end{array}$ & $\begin{array}{l}15 \text { to } 30 \\
\text { minutes } \\
\text { reading } \\
\text { during two } \\
\text { periods for } \\
\text { one day }\end{array}$ & $\begin{array}{c}\mathrm{TSP} \\
\mathrm{CO} \\
\mathrm{CO}_{2} \\
\mathrm{NO}_{2} \\
\mathrm{SO}_{2} \\
\text { Benzene }\end{array}$ & $\begin{array}{c}2.9 \pm 0.84 \mathrm{mg} / \mathrm{m}^{3} \\
2.4 \pm 0.89 \mathrm{ppm} \\
1597 \pm 245.5 \mathrm{ppm} \\
0.019 \pm 0.005 \mathrm{ppm} \\
0.046 \pm 0.01 \mathrm{ppm} \\
0.3 \pm 0.11 \mathrm{ppm}\end{array}$ & $\begin{array}{c}1.4 \pm 0.13 \mathrm{mg} / \mathrm{m}^{3} \\
1.3 \pm 0.27 \mathrm{ppm} \\
1363 \pm 292 \mathrm{ppm} \\
0.01 \pm 0.003 \mathrm{ppm} \\
0.029 \pm 0.004 \mathrm{ppm} \\
0.14 \pm 0.03 \mathrm{ppm}\end{array}$ & $\begin{array}{c}\text { Avg. } \\
\text { between } \\
15 \text { and } 34\end{array}$ \\
\hline $\begin{array}{l}\text { (Alsubaie, } \\
\text { 2014) }\end{array}$ & $\begin{array}{c}\text { Estimated } \\
\text { year of } \\
\text { study: } \\
\text { Academic } \\
\text { year of } 2013\end{array}$ & $\begin{array}{l}\text { 36 elementary } \\
\text { public schools: } \\
\\
-26 \text { formal } \\
\text { schools } \\
\text { (governmental } \\
\text { constructed) } \\
\text { - } 10 \text { rented schools }\end{array}$ & $\begin{array}{c}\text { Spot- } \\
\text { measurement } \\
\text { five times } \\
\text { during two } \\
\text { periods for } \\
\text { one day }\end{array}$ & $\mathrm{CO}_{2}$ & $1266 \pm 390 \mathrm{ppm}$ & $1672 \pm 616 \mathrm{ppm}$ & $\begin{array}{c}\text { Not } \\
\text { provided }\end{array}$ \\
\hline
\end{tabular}


level. The authors stressed on the need to reconfigure the design of public schools in KSA, to limit and control air pollutants' levels and provide sufficient ventilation using both mechanical and natural means.

In Jeddah city, using university students, a study was conducted to test the impact of $\mathrm{CO} 2$ concentration on students' cognitive performance (Ahmed et al., 2017) in two typical classrooms. Except for temperature and $\mathrm{CO} 2$ concentration levels, environmental parameters including sound level, lighting intensity, air velocity, and $\mathrm{RH}$, were kept within constant ranges during the study. Participants were instructed to avoid intense physical activity 12 hours prior to participation, avoid drinking coffee, soda, energy drinks, and to have adequate sleeping times. No restrictions were made on their clothing. Monitoring was performed under nine different exposure conditions, combining three temperatures $\left(20,23\right.$, and $\left.25{ }^{\circ} \mathrm{C}\right)$ and three CO2 levels $(600,1,000,1,800 \mathrm{ppm})$. Measurements were repeated on schooldays for five weeks, from 08:30 to $15: 00$. 499 students participated in the study. Performance tests included; Continuous Performance Test (CPT) for assessing attention tasks; Match to Sample (MTS) for memory tasks; and Behavioral Assessment and Research System (BARS) for cognitive performance. Results revealed that exposure to $\mathrm{CO} 2$ concentrations of 1,000 ppm and 1,800 ppm deteriorated accuracy rates in performing memory and attention tasks, as compared to being exposed to $\mathrm{CO} 2$ concentrations of $600 \mathrm{ppm}$. Symptoms like dizziness, headache, and fatigue increased the percentage of errors for cognitive tasks. These symptoms might be related to poor ventilation in the examined settings. The author stated that the AC type installed was a Central System (CAV); however, the damper of the fresh air was kept shut by the building operators, preventing freshairdilution of airpollutants (Ahmed etal.,2017).

Alzahrani (2018) developed a model to explore the effect of IEQ on teachers' performance in educational buildings in KSA. This study is considered as one of the first in KSA to focus on teachers' performance and perception of comfort. It involved thermal comfort, IAQ, lighting quality and acoustical performance. For the sake of this review paper, only IAQ and thermal parameters were included.

To develop the primary data of IEQ conditions in KSA classrooms, Alzahrani (2018) conducted objective field measurements for eight physical environmental factors at Jeddah Technical College (JTC), as well as subjective surveys (124 participants) to evaluate teachers' perception of indoor conditions. Collected data were analyzed and used for developing the assessment statistical model using the Artificial Neural Network (ANN) and algorithm method. The data were collected for six months; two months at each season to cover the annual academic range. 42 occupied classrooms were examined during the autumn term, 44 classrooms in Winter, and 38 in Spring term (total number $=124$ classrooms). Measurements were recorded three times in each examined classroom over a thirty-minute period for one day. It was found that the environmental measurements in all examined classrooms were relatively in good compliance with the standards recommended measures. Average $\mathrm{CO} 2$ concentration levels varied between $632 \mathrm{ppm}$ to $867 \mathrm{ppm}$ with an overall of $87 \%$ of readings being within the recommended value. Considering the subjective surveys, $59 \%$ of teachers reported that IAQ was acceptable, and $65 \%$ believed that IAQ had positive performance impact. In consistency with Ahmed et al. (2017) results, Alzahrani (2018) indicated the relationship between CO2 levels (representing IAQ) and performance; that when $\mathrm{CO} 2$ concentration decreased, performance of teachers improved. Optimal $\mathrm{CO} 2$ level to maximize performance was in the range of $650 \mathrm{ppm}$.

In conclusion, the above studies show that $\mathrm{CO} 2$ concentration levels in public schools were above the maximum limit of 1,000 ppm, mainly due to overcrowded classrooms and inadequate ventilation rate. In addition, concentrations of $\mathrm{SO} 2$ and Benzene were over the standard values in $50 \%$ of the investigated classrooms in the public schools (El-Sharkawy, 2014). CO2 levels in university classrooms reported lower concentrations varying between 632 to $867 \mathrm{ppm}$ (Alzahrani, 2018). However, Ahmed et al. (2017) raised an essential issue associated with operating mechanical AC systems in university classrooms. They pointed out that although a central ventilation system has been installed, the admission of fresh air was blocked by the building operators, resulting in an accumulated air pollutant concentration which might impact students' wellbeing. Creating awareness and providing practical guidance on operating healthy $\mathrm{AC}$ systems is a priority to ensure a better classroom indoor environment. 


\subsection{Indoor Environmental Studies}

Radon is one of the significant IAQ pollutants in buildings. The WHO (2009) reported that radon is the main cause of lung cancer after cigarette smoking. The main route for indoor radon is the leaking of radon from soil to building through cracks in floor, foundation, or walls below ground level (the International Commission on Radiological Protection - ICRP, 2011). Al-Khateeb (2017), investigated the seasonal variations of indoor radon concentration levels inside King Abdulaziz Medical City (KAMC) buildings in Riyadh City. This medical city consists of multiple buildings; King Fahd Hospital, Administration Building, Research Center, and included three educational buildings related to the College of Medicine (COM-A, COM-B, and COM-F). Concentrations were measured using 400 dosimeter (200 for winter measurements and 200 for summer) placed in random locations at ground floor at each building, for a period of three months for Winter and three months for Summer season. Results show that radon level had different behavior from one building to another although they all have the same meteorological conditions. These variations were due to amount of fresh air supplied by the AC systems, and the floor under examination being ground or basement level. It was found that the Administration building (with basement level), exhibited a significant difference in radon levels between the different meteorological seasons, as compared to the other buildings without basement. Radon winter concentrations $(44.3 \pm 3.1 \mathrm{~Bq} \mathrm{~m} 3)$ was higher than the summer levels $(26.1 \pm 1.7 \mathrm{~Bq}$ m3). Educational buildings COM-A, and COM-B (with no basement) showed no difference between winter and summer concentrations of radon. However, in the educational building COM-F, radon concentrations in winter were greater than summer, which can be attributed to the excavation work as this building was newly-built. The radon concentration in the hospital building during winter was lower, and generally performing well due to its good ventilation system that supplies $70 \%$ fresh air. Overall, results of radon concentration range (max, min, and avg.) in all examined buildings, during both seasons, were far below the range levels $(75-150 \mathrm{~Bq} / \mathrm{m} 3)$ needing mitigation as recommended by ICRP (2011).

Indoor and outdoor particulate matter levels (PM10, PM2.5, PM1) were measured in fifteen
Jeddah primary schools, located in various traffic density zones; six of which located in North Jeddah while the rest ( 9 schools) located in the South (Alghamdi, 2013). It was found that the indoor PM concentrations were higher than the levels outdoors, except for some schools at the North and South where PM10 levels were higher outdoors; with highest indoor and outdoor PM10, PM2.5, PM1 concentrations measured at the schools in South Jeddah. This can be attributed to the infiltration of outdoor air, and the generation of particles due to the presence of occupants and their metabolic activities as respiration and movement. Around $37 \%$ of the examined schools reported indoor PM10 levels exceeding the maximum 24-h and annual concentrations permissible by the WHO and EPA. Also, around $47 \%$ of the examined schools showed PM2.5 levels higher than the maximum 24-h values recommended by WHO. All examined schools (100\%) reported PM1 concentrations exceeding the annual value recommended by WHO. Alghamdi (2013) indicated that the indoor PM concentrations in classrooms at all examined schools showed increased values with the presence of students.

A study was conducted in Jeddah to assess the heavy metal contamination levels in Classroom Air Conditioner Filter (CACF) as a way to provide useful information about IAQ in school environment and the associated health hazards and diseases (Alghamdi et al., 2019). CACF particle samples were collected from ten primary schools located in urban, suburban and residential areas to compare findings and relate IAQ conditions to location. 40 samples were collected, during the months of April-May 2019; four samples from AC filters of different classrooms at each examined school. CACF particles selected for the investigation were the ones measuring $\leq 38 \mu \mathrm{m}$ diameter in order to increase metal concentration as compared to dust particles, and because smaller particles pose higher health risks (Li et al., 2013), remain airborne for longer time, and can be transported easily (Soltani et al., 2015). Results indicate that the levels of heavy metals in CACF at urban schools were higher than those at suburban and residential schools. This is due to the influence of heavy traffic emissions in the urban areas. Urban schools were heavily contaminated by $\mathrm{Pb}$ and $\mathrm{Cd}$. Suburban and residential schools were moderately to heavily contaminated by $\mathrm{Pb}$ and $\mathrm{Cd}$. All schools were moderately contaminated by $\mathrm{Zn}$ and $\mathrm{As}$ (Table 4). Although some of the measured met- 
Table 4. The mean concentrations $(\mu \mathrm{g} / \mathrm{g})$ of heavy metals in CACF particles of examined Jeddah schools. Data extracted from source: (Alghamdi et al., 2019).

\begin{tabular}{cccccccccccc}
\hline School & $\mathbf{F e}$ & $\mathbf{M n}$ & $\mathbf{Z n}$ & $\mathbf{P b}$ & $\mathbf{C d}$ & $\mathbf{V}$ & $\mathbf{C o}$ & $\mathbf{N i}$ & $\mathrm{As}$ & $\mathbf{C r}$ & $\mathbf{C u}$ \\
\hline $\begin{array}{c}\text { Urban } \\
\text { Schools }\end{array}$ & 8,650 & 481.7 & 462.3 & 200.3 & 3.1 & 68.3 & 11.8 & 53 & 11.7 & 52 & 113.3 \\
\hline $\begin{array}{c}\text { Suburban } \\
\text { Schools }\end{array}$ & $8,166.7$ & 360.8 & 319.8 & 120 & 1.8 & 40.3 & 9.3 & 35 & 8.2 & 39.7 & 87.4 \\
\hline $\begin{array}{c}\text { Residential } \\
\text { Schools }\end{array}$ & $9,438.2$ & 332.8 & 246.1 & 43.3 & 1.4 & 23.3 & 3.3 & 19 & 3.9 & 29 & 63 \\
\hline
\end{tabular}

al particles were within the acceptable range recommended by EPA, their accumulation in body tissues can cause serious health impact (Martin et al., 2009).

In addition, it was reported that ingestion is the main way of children exposure to heavy metal particles in classrooms of Jeddah schools, followed by dermal contact and inhalation. Heavy metal particles can cause some serious health issues for children, and some can be a source for cancer risks (ones found in Jeddah schools were: cadmium $(\mathrm{Cd})$, chromium $(\mathrm{Cr})$, arsenic (As), lead $(\mathrm{Pb})$, nickel $(\mathrm{Ni})$, and cobalt $(\mathrm{Co})$. Co (56.3\%) and $\mathrm{Ni}(21.1 \%)$ were the predominant contributors to cancer risks, whereas $\mathrm{Pb}(33.9 \%)$ and $\mathrm{As}(25.8 \%)$ were the predominant contributors to non-cancer risks in Jeddah schools. The rank order of schools in terms of Carcinogenic and non-carcinogenic risks on children associated with heavy metal particles was: urban schools $>$ suburban schools $>$ residential schools.

Polycyclic Aromatic Hydrocarbons (PAHs) are a significantly related to school IAQ. PAHs are organic compounds distributed in both gaseous and particulate forms in the atmosphere and indoor air (Dat and Chang, 2017). They are atmospheric pollutants recognized as toxic, carcinogenic, and mutagenic compounds (Jyethi and Khillare, 2014; Krugly et al., 2014). Dust-bound PAHs originate from both nature and human activity pollutants (Dat and Chang, 2017). PAHs' Natural sources include volcanic eruptions and woods' fire. Human activity pollutants include indoor sources, such as cooking and heating processes and tobacco smoke, and outdoor sources such as fossil fuel combustion (Zhang et al., 2020; Hassan, 2018; Dat and Chang, 2017; Chen et al., 2016).

Alghamdi et al. (2020) studied the concentrations of dust-bound Polycyclic Aromatic Hydrocarbons (PAHs) in Jeddah's schools and the associated potential health risks to students. A total of $16 \mathrm{PAH}$ compounds were examined from 40 classroom AC filter samples collected from 10 schools located in three areas, urban, suburban, and residential areas. Schools located in urban areas reported the highest average of PAHs due to highest traffic density while the lowest average were found in the residential areas. The PAH compounds with the highest concentrations identified in this study were benzo(a)pyrene (BaP), considered as an indicator of total exposure to PAH compounds and a marker of overall carcinogenicity for these PAHs, and Dibenz[a,h]anthracene (DBA). Also, it was found that there was no specific indoor source of PAHs; however, combustion emissions from vehicular traffic around schools were the main outdoor source; reaching classroom via infiltration. Inhalation, ingestion, and dermal contact are the three main pathways of PAHs exposure. Alghamdi et al. (2020) reported that the major exposure pathways for cancer risks associated with PAHs were the dust ingestion and direct dermal contact.

The health risks from exposure to classroom dust-bound PAHs were assessed in this study using a standard assessment model developed by the EPA. The values resulting from these standard assessment tests (LAR and TLCR) indicated that schools with highest health risk were in the urban areas, followed by suburban then residential. However, all reported values were lower than the high-risk-value showing that there was no current significant risk of PAHs on students. Thus, the risk might increase if the dust-bound PAHs levels were to increase (Alghamdi et al., 2020).

To summarize, IEQ evaluation in KSA were all unique in their investigated indices and to the areas where they were conducted making incomparable. However, these studies give insight to IAQ KSA educational IEQ. Alghamdi et al. (2019) emphasized the importance of monitoring the levels 
of heavy metal particles in classrooms regularly to ensure better IAQ and lower health risks. Investigating and identifying the sources of these heavy metals, especially $\mathrm{Pb}$ and $\mathrm{Cd}$ as they were found with the highest concentrations, would assist in controlling their levels and deterring the associated health risks. Also, in a recent study, Alghamdi et al. (2020) reported that the levels of PAHs need to be assessed regularly to ensure their concentrations are kept below the permissible values by standards for healthy classroom. Particulate matters possess a significant risk to student health in KSA schools as Alghamdi (2013) reported. Radon concentrations in all examined buildings were below the level requiring mitigation actions; however, buildings with basement showed higher indoor radon levels compared to buildings without (Al-Khateeb et al., 2017).

\subsection{Thermal Conditions in Classroom Setting}

Thermal conditions represented in air temperature and RH dictate occupants' comfort and greatly impact their wellbeing and performance. In reference to previously discussed study of Ahmed et al. (2017), where the effect of three levels of temperatures were tested on students' thermal comfort and performance, it was found that at all exposure conditions at which the temperature was set to $20{ }^{\circ} \mathrm{C}$, the percentage of errors increased significantly. Fast performance at cognitive tasks was observed when temperature was set at $25-23{ }^{\circ} \mathrm{C}$ as compared to $20{ }^{\circ} \mathrm{C}$, but intolerable thermal discomfort impaired focusing abilities. The variables that were found to be statistically-significantly associated with the accuracy and speed of students' performance were: ethnicity, age, clothing insulation, physical activity, and thermal comfort sensations (Ahmed et al., 2017).

In Alzahrani's et al. (2020) study, 84\% of temperature readings (between 21.5-26.5 ${ }^{\circ} \mathrm{C}$ ) complied with the recommended range of ASHRAE Standard-55 (2017). 93\% of RH records (between 46-71\%) were within the standard range. Considering the subjective surveys, $60 \%$ of participants found thermal conditions to be acceptable, and $70 \%$ believed to positively impacted their performance. Performance improved with increasing temperatures to up to $25{ }^{\circ} \mathrm{C}$, while having $\mathrm{RH}$ up to $68 \%$ and ventilation rate up to $0.40 \mathrm{~m} / \mathrm{s}$. Optimized measures stated by
Alzahrani et al. (2020) for enhancing performance are temperatures between $23-25{ }^{\circ} \mathrm{C}$, RH between $60-68 \%$, and ventilation rate of $0.3 \mathrm{~m} / \mathrm{s}$.

In order to understand thermal comfort variations among gender, Al-Khatri et al. (2020) conducted two studies to investigate and compare the thermal conditions of female and male high schools, during the cool season. The first study was done in five female schools in Muscat, Oman, while the other study focused on three male schools in Jeddah, KSA. Three classrooms, each conditioned by two split units and ceiling fans, were selected at each examined school. Objective measurements of indoor and outdoor air temperature, globe temperature, $\mathrm{RH}$ and air velocity were performed. In addition, two survey questionnaires consisting of groups of questions were performed to investigate students' thermal comfort according to ASHRAE sensation scale (from -3 being cold, to +3 being hot). Indoor thermal conditions were weakly associated with the outdoor due to the complete dependence on mechanical AC. $77 \%$ of indoor air temperature in Oman female-schools ranged between 24-26 ${ }^{\circ} \mathrm{C}$. In the KSA male-schools, $69 \%$ of the indoor temperatures were between $26-28{ }^{\circ} \mathrm{C}$, and $26 \%$ were between $23-25{ }^{\circ} \mathrm{C}$. Students' insulation level was determined according to their clothing; female uniform was estimated to be 1.07 clo while the Saudi male students had lower insulation level of 0.74 clo for wearing traditional white thowb. Activity level was around 1 met as students were seated for reading and writing in both studies (Al-Khatri et al., 2020).

Based on questionnaire, $55 \%$ of female students voted (neutral) in the ASHRAE sensation scale, and another $20 \%$ voted (slightly cool). On the other hand, male students' votes increased on the warm side of the thermal scale with (warm) category receiving highest votes among other categories (29\%). Al-Khatri et al. (2020) results show that females tend to be more sensitive to cold conditions, while males are more sensitive to hot conditions. In addition, $60 \%$ of the students in both studies showed their preference of increased air velocity. When discussing thermal adaptive behavior, the female students were more aware of other adaptive actions besides turning $\mathrm{AC}$ on, as compared with the male students. $36 \%$ of female students reported using AC for cooling, and others used windows and fans as means of improving the thermal conditions in their classrooms. However, $46 \%$ male students depended mostly on using AC for cooling and some reported 
altering their clothing level, with a suggestion that male students are more $\mathrm{AC}$ dependent.

A Griffiths' method was applied in this study in order to compute the neutral temperature, and the $80 \%$ and $90 \%$ acceptability limits. Neutral temperature for the female students was estimated at $24.3 \pm 1.09{ }^{\circ} \mathrm{C}$, and at $26.1 \pm 0.92{ }^{\circ} \mathrm{C}$ for the male students. The $80 \%$ acceptability limits were 22.6-26.1 ${ }^{\circ} \mathrm{C}$ and $24.3-27.8^{\circ} \mathrm{C}$ for the female and male students, respectively. The $90 \%$ acceptability limits were $23.3-25.4{ }^{\circ} \mathrm{C}$ and $25.0-27.1{ }^{\circ} \mathrm{C}$ for the female and male students, respectively (Al-Khatri et al., 2020).

In summary, indoor air temperatures set between 23-25 ${ }^{\circ} \mathrm{C}$ improved occupants' performance (Ahmed et al., 2017; Alzahrani et al., 2020). According to a survey for set temperatures in educational buildings in Jeddah, $20{ }^{\circ} \mathrm{C}$ was the most common set temperature, found in over $80 \%$ of the surveyed buildings (Ahmed et al., 2017). This reflects the need to reconsider the operational of AC systems to ensure a comfort without unnecessary energy loss. Al-Khatri et al. (2020) reported that female students tend to be more sensitive to cold conditions, while males are sensitive to hot conditions. They suggested that level of insulation of the former is heavier than the latter. However, another factor that could influence the results were the mean temperature the male school were $26-28{ }^{\circ} \mathrm{C}$ compared to female schools mean temperature $24-26{ }^{\circ} \mathrm{C}$. Understanding the thermal preferences and perceived comfort is an essential step that can lead to reducing reliance on mechanical AC systems for cooling and ventilating.

\subsection{Epidemiological Studies on Health and Contamination}

Microbiological IAQ greatly influence students' mental health, physical development, and performance. High fungal and bacterial contamination is associated with respiratory issues, asthma, and can lead to absenteeism (Mendell and Heath, 2005; Becerra et al., 2020). The microbial content of indoor air depends mainly on occupant-density, occupant activity, ventilation, and building age.

A study conducted at 12 educational buildings

in Dammam investigated the fungal and bacterial colonization on AC filters, walls, ceiling, toilet and cafeteria in order to identify the contamination risks impacting IAQ (Hassan and Al-Abdalall, 2011). A total of 240 samples were obtained and analyzed. Results revealed that $45 \%$ of the fungal isolates were collected from the walls, $32 \%$ from ceiling, $17 \%$ from toilets, and 5\% from cafeteria. Dust samples were collected from classroom AC. These samples recorded six fungal genera with various species affecting the classroom IAQ. This diversity and high-density of reported findings indicated that $\mathrm{AC}$ systems are significantly linked with fungal contamination. In addition, it showed that all tested buildings suffer of microbial contamination and confirmed that inefficient maintenance of the AC systems caused an accumulation of microorganisms (fungi and bacteria) and a potential source of IAP (Hassan and Al-Abdalall, 2011). The study also analyzed the impact of changes in indoor air temperature and $\mathrm{RH}$ on fungi growth in the isolates obtained from the examined buildings (Hassan and Al-Abdalall, 2011). The most frequently isolated fungi reported from the AC system samples, Aspergillus niger, Aspergillus flavus and Stachybotry, were used to test growth rate at various temperatures $\left(5,10,15,20,25,30,35,40,45^{\circ} \mathrm{C}\right)$ and different RH $(35,50,65,75,90,100 \%)$. It was found that the optimum temperature for the three tested fungi species was $25{ }^{\circ} \mathrm{C}$, and the optimum $\mathrm{RH}$ was $100 \%$.

Another study investigated classrooms indoor air for 25 middle schools in Riyadh, with the aim of estimating indoor airborne bacterial contaminations and health hazards to create standards for IAQ control (Al-Mijalli, 2016). 252 $\mathrm{AC}$ air filters samples were collected at public and private schools. Al-Mijalli (2016) found that highest level of bacterial contamination was detected in classrooms during lessons. In addition, high concentrations of bacterial contamination were observed in public schools where classrooms are usually more crowded. Sample results showed that there were different bacterial species with majority showing resistance to one or more antimicrobial compounds. Al-Mijalli reported that lack of $\mathrm{AC}$ cleaning may result in microbial growth, causing several diseases. Implementing indoor air distribution techniques help in controlling the transmission of infection and the stratification of pollutants (Haghighat and Donnini, 1999).

Sebiany et al. (2018) investigated the main IAP impacting the physical growth of school 
students (male aged 6-12 years) in Dammam. This cross-sectional epidemiological study was carried out in five primary schools; one in a residential area, another from a commercial area, and three from an industrial area. A total of 851 boys participated in the study. These participants lived and went to school in the same selected area for at least one academic year. Four indoor and outdoor air pollutants, including $\mathrm{SO} 2, \mathrm{CO}, \mathrm{NO} 2$ and $\mathrm{CO} 2$, were measured for a two-hour period, five-minute intervals. Also, indoor and outdoor TSP was sampled using a portable air sampler. A questionnaire was distributed on students' parents or caregivers to collect information on participants' demographics and their socioeconomic status. In addition, predicted anthropometric measurements, student's body weight and height, were calculated using the 50th percentile values from Harvard International Standard and the national Saudi standard (Sebiany et al., 2018). Anthropometric measurements included body weight, height, mid-arm circumference, and triceps skin-fold thickness. They are a significant reference for evaluating child growth: an increase in the physical body measurements indicates a good progress in growth and health (Falkner and Tanner, 1986). Results of the mean anthropometric values were the highest for students in the residential area, followed by the commercial then industrial areas (Sebiany et al., 2018). It was found that there is a significant relationship between student's anthropometric values and the exposure to $\mathrm{CO}$ and $\mathrm{NO} 2$ pollutants. Students who were exposed to higher levels of $\mathrm{CO}$ and $\mathrm{NO} 2$ showed lower anthropometric measures. Similarly, the exposure to TSP impacted the body measures negatively (Sebiany et al., 2018). The measured environmental data revealed that the indoor and outdoor levels of TSP were higher than permissible values recommended by WHO and National Saudi Standards, with highest measures being recorded in the industrial area due to industrial emissions and heavy traffic. NO2 indoor level exceeded the values recommended by WHO, but within Saudi Standard values. Other measured IAP were lower than the maximum permissible values recommended by WHO and the National Saudi Standards (Table 5).

The association between IAP and the anthropometrical measurements of students in Dammam. The concentrations of air pollutants were generally higher in the industrial areas compared to commercial and residential areas (Sebiany et al., 2018). Al-Mijalli (2016), and Hassan and Al-Abdalall (2011) also concluded that health risks and bacterial contaminations are of a serious concern in KSA public schools specifically because of the increased number of students, and the inefficient maintenance and cleaning of AC systems causing an accumulation of dust and microbial growth. Intervention need to be considered to educational spaces that comply with the IAQ standards.

\subsection{Technical Application for IAQ Assessment}

Technical application to investigate and advance educational IAQ have a great impact on developing strategies and corrective processes. Two studies by Al-Sulaihi et al. (2015) were concerned with developing a framework for assessing and improving IEQ of educational buildings in KSA using Building Information Modeling (BIM). A College of Engineering building in Riyadh was selected to implement the proposed framework. Standards' IEQ recommended values were inserted to the database. Sample measurements of thermal comfort, IAQ and visual comfort parameters were collected then integrated with the BIM model to compare the measured values with the standard ones, detecting IEQ problems and identifying poor performance.

Table 5. Mean values of IAP in the different examined school areas in Sebiany et al. study.

\begin{tabular}{cccccc}
\hline $\begin{array}{c}\text { Pollutant } \\
(\mathbf{p p m})\end{array}$ & $\begin{array}{c}\text { Residential } \\
\text { Area }\end{array}$ & $\begin{array}{c}\text { Commercial } \\
\text { Area }\end{array}$ & Industrial Area & $\begin{array}{c}\text { WHO standard } \\
\text { measure }\end{array}$ & $\begin{array}{c}\text { Saudi Standard } \\
\text { measure }\end{array}$ \\
\hline $\mathbf{C O}(\mathbf{p p m})$ & $7.2 \pm 0.27$ & $9.41 \pm 0.94$ & $10.21 \pm 0.56$ & 35 & 35 \\
\hline $\mathbf{C O}(\mathbf{p p m})$ & $571.25 \pm 15.48$ & $818.12 \pm 64.31$ & $931.12 \pm 23$ & 1000 & 1500 \\
\hline $\mathbf{N O}(\mathbf{p p m})$ & $0.0175 \pm 0.002$ & $0.275 \pm 0.119$ & $0.321 \pm 0.015$ & 0.053 & 0.35 \\
\hline $\mathbf{S O} \mathbf{O}_{\mathbf{2}}(\mathbf{p p m})$ & $0.054 \pm 0.001$ & $0.094 \pm 0.0019$ & $0.145 \pm 0.0017$ & 0.14 & 0.169 \\
\hline $\mathbf{T S P}\left(\boldsymbol{\mu g} / \mathbf{m}^{\mathbf{3}}\right)$ & $686.1 \pm 4.33$ & $604.16 \pm 96.38$ & $727.51 \pm 96.39$ & 150 & 340 \\
\hline
\end{tabular}


Alhebshi et al. (2020) conducted a subjective assessment of occupants' thermal comfort in two university classrooms in Jeddah through Predictive Mean Vote (PMV) questionnaire form. In addition, sample measurements of air temperature and air velocity were recorded at various points within the examined classrooms for a duration of 10 minutes in order to compare results and evaluate the existing thermal conditions using ASHRAE Standard 55. Results indicates that the PMV values of the existing conditions at the examined classrooms did not meet ASHRAE 55 (2017) minimum requirements. In order to improve thermal comfort while avoiding draft sensation, different configurations of air supply diffusers were tested using Computational Fluid Dynamics. These strategies included Mixing Ventilation (MV), Displacement Ventilation (DV), and Stratum Ventilation (SV). It was found that $\mathrm{SV}$ and DV strategies resulted in enhanced PMV indices and consistency in air temperature and air velocity distribution (Alhebshi et al., 2020).

\section{Conclusion}

The aim of this paper is to review available national studies investigating classrooms' IAQ to identify the level of pollution risks to the quality of indoor air existing in educational facilities in KSA. All indicators emphasize the limitation in number of studies on the national scale, and the need for further investigations tackling different KSA regions and covering the basic IAP indices. Conclusions from IAQ and thermal conditions and can be summarizes as follows:

- Classrooms $\mathrm{CO} 2$ concentration were significantly higher than $1,000 \mathrm{ppm}$ the permissible measure by ASHRAE (Avg. among examined schools were between 1200 to $1700 \mathrm{ppm}$ ), and were in poorer environmental conditions when compared to classrooms in higher educational facilities (El-Sharkawy, 2014; Alsubaie, 2014; Alzahrani, 2018; Sebiany et al., 2018).

- $\mathrm{CO} 2$ levels are mainly influenced by occupant activity rather than outdoor conditions (El-Sharkawy, 2014).

- NO2, CO, SO2, Benzene, and TSP were the major IAP with highest levels exceeding the recommended values by standards, compared with other pollutants (Al-Rehaili, 1999; Al-Rehaili, 2002; El-Sharkawy, 2014;
Sebiany et al., 2018).

- Schools located in industrial and urban areas showed higher IAP when compared to schools in residential areas (Alghamdi, 2013; Sebiany et al., 2018; Alghamdi et al., 2019; Alghamdi et al., 2020).

- $\mathrm{Pb}, \mathrm{Cd}$, and As were the main heavy metal particles found in air in examined classrooms with concentrations exceeding the permissible measures by standards (Alghamdi et al., 2019). Some of these heavy metal particles causes carcinogenic risks for occupants.

- Ingestion was found to be the major exposure pathway for PAHs air pollutants (Alghamdi et al., 2020) and heavy metals (Alghamdi et al., 2019), followed by dermal contact then inhalation.

- Particulate Matters PM with small size were found to be a significant IAP in educational buildings in KSA. $100 \%$ of examined schools by Alghamdi (2013) reported PM1 indoor level exceeding the annual average recommended by WHO.

- High level of microbial contamination and diversity in bacterial and viral species were found in classrooms AC filtration in studies conducted in educational buildings in KSA (Hassan and Al-Abdalall, 2011; Al-Mijalli, 2016).

- AC systems are significantly linked to fungal and IAP, and they are a main source of infection if not maintained and cleaned effectively since accumulations of microorganisms pose a potential risk for poor IAQ (Hassan and Al-Abdalall, 2011; Al-Mijalli, 2016).

- Samples collected from classroom walls and ceilings recorded high levels of microbial contamination indicating that the examined educational buildings suffer of contamination and infection risks (Hassan and Al-Abdalall, 2011).

- Indoor thermal conditions impact fungal growth rate; optimum indoor air temperature was found to be $25^{\circ} \mathrm{C}$ and optimum RH was $100 \%$ for the tested fungal species (Hassan and Al-Abdalall, 2011).

- Uncomfortable thermal sensations, as high and low air temperature, and high $\mathrm{CO} 2$ concentrations exceeding the recommended value, impacted students' cognitive abilities 
and task accuracy negatively (Ahmed et al., 2017).

- Gender of occupants impacts their thermal sensations in spaces and influences their adaptive behavior as a response to the thermally-uncomfortable settings. Females tend to be sensitive to cold conditions while male participants were more sensitive to warmer conditions (Al-Khatri et al., 2020).

\section{Limitations}

The systematic review reveals the limited number of studies that would reflect the local context. This leads to inconclusive finding and difficulty to conduct meta-analysis as some publications were unique in terms of examined aspects and variables. Some reviewed studies, failed to acknowledge the variables impacting measured indices such as; tracking of occupant count, type of AC system installed, and position of openings.

\section{Recommendation}

- Further studies are needed to identify common sources of indoor pollution in KSA school and procedure to eliminate them. This include improving the mitigation of heavy metal particles and control the transmission of bacterial infection and risks.

- Further studies are needed on optimal mechanical AC systems configuration for KSA climates. Where $\mathrm{AC}$ has an essential role in ensuring thermal comfort and controlling of indoor air contamination spread.

- Further attention is needed for this topic on local level and context in order to create awareness and to guide policies and decision makers, where solutions to elevate the classroom environmental can be developed.

- Acknowledgments: The authors would like express their appreciation to Dr. Heba Sabbagh, for her detailed comments and feedback during the development of the review manuscript.

\section{References}

Ahmed, G., \& Mohammed, R. The Effects of Indoor Temperature and $\mathrm{CO} 2$ levels as an Indicator for Ventilation Rates on Cognitive Performance of Adult Female Stu- dents in Saudi Arabia [PhD Thesis]. (2017). UCL (University College London).

Ahmed, R. J., Mumovic, D., \& Ucci, M. Impact of Indoor Temperature and $\mathrm{CO} 2 \mathrm{Lev}-$ els on Occupant Thermal Perception and Cognitive Performance of Adult Female Students in Saudi Arabia. International Building Physics Conference. 5. 2018; https://doi.org/10.14305/ibpc.2018.ie-1.05

Ahmed, R. J, Mumovic, D, Ucci, M. The effect of indoor temperature and $\mathrm{CO} 2$ levels on cognitive performance of adult females in a university building in Saudi Arabia. CISBAT 2017 International Conference-Future Buildings \& Districts. Energy Procedia. 2017; 122: 451-456. https:// doi.org/10.1016/j.egypro.2017.07.378

Alghamdi, M.A. Indoor/ Outdoor Particulate Matter Concentrations at Some Elementary Schools in Jeddah, Saudi Arabia. Met., Env. \& Arid Land Agric. Sci. 2013; 24 (1): 77-95. DOI: 10.4197/Met. 24-1.6

Alghamdi, M.A., Hassan, S.K., Alzahrani, N.A., Almehmadi, F.M., Khoder, M.I. Risk Assessment and Implications of Schoolchildren Exposure to Classroom Heavy Metals Particles in Jeddah, Saudi Arabia. International Journal of Environmental Research and Public Health. 2019; 16: 5017; doi:10.3390/ijerph 16245017

Alghamdi MA, Hassan SK, Alzahrani NA, Al Sharif MY, Khoder MI. Classroom Dust-Bound Polycyclic Aromatic Hydrocarbons in Jeddah Primary Schools, Saudi Arabia: Level, Characteristics and Health Risk Assessment. Int J Environ Res Public Health. 2020;17(8):2779. doi:10.3390/ijerph17082779

Alhebshi, O., Bayoumi, M., Sabbagh, M. Improving thermal sensation in classrooms with respect to draft avoidance by optimizing the mechanical air supply method. Proceedings of 86th Research World International Conference, Jeddah, Saudi Arabia. 2020.

Al-Khateeb, H. M., Nuseirat, M., Aljarrah, K., Al-Akhras, M., Bani-Salameh, H. Seasonal variation of indoor radon concentration in a desert climate. Applied Radiation and Isotopes. 2017; 130: 49-53. https:// 
doi.org/10.1016/j.apradiso.2017.08.017

Al-Khatri, H., Alwetaishi, M., Gadi, M. B. Exploring thermal comfort experience and adaptive opportunities of female and male high school students. Journal of Building Engineering. 2020; 31,101365. https:// doi.org/10.1016/j.jobe.2020.101365

Al-Mijalli S. Bacterial contamination of indoor air in schools of Riyadh, Saudi Arabia. Air \& Water-B. Dis. 2016: 6. https:// doi.org/10.4172/2167-7719.1000131

Alrashed, F., Asif, M. Climatic classifications of Saudi Arabia for building energy Modelling. The 7 th International Conference on Applied Energy - ICAE2015. Energy Procedia. 2015; 75:1425 - 1430.

Al-Rehaili, A.M. Outdoor-indoor air quality in Riyadh: SO2, NH3, and $\mathrm{HCHO}$. Environmental Monitoring and Assessment. 2002; 79(3): 287-300. https:// doi.org/10.1023/A:1020253113557

Al-Rehaili, A. Outdoor-indoor air quality in Riyadh: Particulate Matter, $\mathrm{Pb}$ and $\mathrm{CO}$. WIT Transactions on The Built Environment. 1999; 44.

Al-Rehaili, A. Outdoor-indoor air quality in Riyadh: NO, NO2, and O3. WIT Transactions on Ecology and the Environment. 1999; 37.

Alsubaie ASR. Indoor air ventilation in primary schools in Eastern Province, Saudi Arabia. Int. J. Curr. Res. 2014; 6: 6552-6557.

Al-Suhaili, I., Al-Gahtani, K., Alsugair, A., Tijani, I. Assessing Indoor Environmental Quality of Educational Buildings Using BIM. Journal of Environmental Science and Engineering. 2015; (B4): 451-458. DOI:10.17265/2162-5263/2015.08.006

Al-Sulaihi, I. A., Al-Gahtani, K. S., Alsugair, A. M., \& Tijani, I. Framework for Assessing the Indoor Environmental Quality for Educational Buildings using BIM. Conference: Scientific Cooperations Workshops on Engineering Branches, At: Istanbul, Turkey. 2015

Alzahrani HM. Developing a model for assessing the effect of physical indoor environment quality on teachers' performance in Saudi educational buildings [unpublished doctoral dissertation]. Faculty of Science and Engineering:
University of Wolverhampton, UK; 2018.

Alzahrani, H., Mohammed, A., Kaushik, A., Goulding, J. and Heesom, D. Evaluating the effects of thermal comfort on teacher performance using Artificial Neural Network, International Journal of Building Pathology and Adaptation, 2020; (in press).

Amoatey, P., Omidvarborna, H., Baawain, M. S., Al-Mamun, A. Indoor air pollution and exposure assessment of the gulf cooperation council countries: A critical review. Environment International. 2018; 121: 491-506.

American Society of Heating, Refrigerating, and Air-Conditioning Engineers [ASHRAE]. ANSI/ASHRAE Standard 55-2017: Thermal Environmental Conditions for Human Occupancy.https://mafiadoc.com/ashrae-standard-55-2017_5c614e2c097c47942e-

8b45e9.html. (accessed October 9, 2019).

American Society of Heating, Refrigerating, and Air-Conditioning Engineers [ASHRAE]. ANSI/ASHRAE Standard 62.1-2013: Ventilation for acceptable indoor air quality. 2013. Atlanta, GA. http://www.myiaire.com/ product-docs/ultraDRY/ASHRAE62.1.pdf (accessed October 9, 2019).

Becerra JA, Lizana J, Gil M, Barrios-Padura A, Blondeau $P$, Chacartegui $R$. Identification of potential indoor air pollutants in schools. J Cleaner Production. 2020; 242: 118420. https:// doi.org/10.1016/j.jclepro.2019.118420

Bluyssen, P. M., Kim, D., Eijkelenboom, A., Ortiz-Sanchez, M. Workshop with 335 primary school children in The Netherlands: What is needed to improve the IEQ in their classrooms?. Building and Environment. 2020; 168, 106486. https:// doi.org/10.1016/j.buildenv.2019.106486

Bower, I., Tucker, R., Enticott, P. G. Impact of built environment design on emotion measured via neurophysiological correlates and subjective indicators: A systematic review. Journal of Environmental Psychology. 2019; 66. https://doi.org/10.1016/j.jenvp.2019.101344

Chen, Y., Shen, G., Huang, Y., Zhang, Y., Han, Y.;Wang, R., Shen, H., Su, S., Lin, N., Zhu, D., et al.. Household air pollution and person- 
al exposure risk of polycyclic aromatic hydrocarbons among rural residents in Shanxi, China. Indoor Air. 2016; 26: 246-258.

Cleary E, Asher M, Olawoyin R, Zhang K. Assessment of indoor air quality exposures and impacts on respiratory outcomes in River Rouge and Dearborn, Michigan. Chemosphere. 2017:1-20. https://doi. org/10.1016/j.chemosphere.2017.08.091

Dat, N.D., Chang, M.B. Review on characteristics of PAHs in atmosphere, anthropogenic sources and control technologies. Science of The Total Environment. 2017; 609: 682693. DOI: $10.1016 / j$.scitotenv.2017.07.204

El-Sharkawy M.F. Study the indoor air quality level inside governmental elementary schools of Dammam City in Saudi Arabia. Int. J. Environ. Health Eng. 2014; 3: 30-37.

Environmental Protection Agency [EPA]. Reference Guide for Indoor Air Quality in Schools. (2010; last updated 2020). Retrieved August 21, 2020, from: https://www.epa.gov/iaq-schools/reference-guide-indoor-air-quality-schools

Environmental Protection Agency [EPA]. Report to congress on indoor air quality: volume II assessment and control of indoor air pollution. EPA/400/1-89/001C. U.S. Environmental Protection Agency: Washington, DC, 1989.

Falkner F, Tanner JM. Human Growth: Developmental Biology, Prenatal Growth. 1986; 2nd ed., Vol. 1. New York: Plenum Press.

Haghighat, F.; Donnini, G. Impact of psycho-social factors on perception of the indoor air environment studies in 12 office buildings. Building and Environment. 1999; 34 (4): 479-503. https://doi. org/10.1016/S0360-1323(98)00034-1

Hassan, A., and Al-Abdalall, A. Populations and distribution of filamentous fungi and bacteria in some educational buildings in Dammam, eastern Saudi Arabia. Journal of Food, Agriculture \& Environment. 2011; 9 (3\&4): 886 - 891

Hassan, S.K. Particle-Bound Polycyclic Aromatic Hydrocarbon in the Atmosphere of Heavy Traffic Areas in Greater Cairo, Egypt: Status, Source, and Human Health
Risk Assessment. Atmosphere. 2018; 9: 368.

International Commission on Radiological Protection [ICRP]. Radiological protection against radon exposure. Draft Report for Consultation. 2011; (Ref 4829-9671-6554).

Jyethi, D.S., Khillare, P.S., Sarkar, S. Risk assessment of inhalation exposure to polycyclic aromatic hydrocarbons in school children. Environmental Science and Pollution Research. 2014; 21: 366-378.

Krugly, E., Martuzevicius, D., Sidaraviciute, R., Ciuzas, D., Prasauskas, T., Kauneliene, V., Stasiulaitiene, I., Kliucininkas, L. Characterization of particulate and vapor phase polycyclic aromatic hydrocarbons in indoor and outdoor air of primary schools. Atmospheric Environment. 2014; 82: 298-306.

Li, H., Zuo, X.J. Speciation and size distribution of copper and zinc in urban road runoff. Bull. Environ. Contam. Toxicol. 2013; 90: 471-476.

Madureira, J., Ines, P., Rufo, J., Ramos, E., Barros, H., Teixeira, J.P., de Oliveira Fernandes, E. Indoor air quality in schools and its relationship with children's respiratory symptoms. Atmospheric Environment. 2015; 118: 145-156. http://0o101mqte.y.https. doi.org.kau.proxy.deepknowledge. io/10.1016/j.atmosenv.2015.07.028

Martin, S., Griswold, W. Human Health Effects of Heavy Metals; Center for Hazardous Substance Research, Kansas State University: Manhattan, KS, USA, 2009; 15: 1-6.

Mendell, M., and Heath, G. Do indoor pollutants and thermal conditions in schools influence student performance? A critical review of the literature. Indoor Air. 2005; 15(1): 27-52.

Moher, D. et al. Preferred Reporting Items for Systematic Reviews and Meta-Analyses: The PRISMA Statement. Annals of Internal Medicine. 2009; 151 (4): 264-269. https://doi.org/10.7326/00034819-151-4-200908180-00135

Mujan, I., Anđelković, A.S., Munćan, V., Kljajić, M., Ružić, D. Influence of indoor environmental quality on human health and productivity - A review. Journal of Cleaner Production. 2019; 217: 646-657. https:// doi.org/10.1016/j.jclepro.2019.01.307 
Panagiotaras, D., Nikolopoulos, D., Petraki, E., Kottou, S., Koulougliotis, D., Yannakopoulos, P., Kaplanis, S. Comprehensive experience for indoor air quality assessment: a review on the determination of volatile organic compounds. Journal of Physical Chemistry \& Biophysics. 2014; 4.5. http://0o101mqte.y.https. doi.org.kau.proxy.deepknowledge.

io/10.4172/2161-0398.1000159

Satish U, Mendell MJ, Shekhar K, Hotchi T, Sullivan D, Streufert S, Fisk WJ. Is $\mathrm{CO} 2$ an indoor pollutant? Direct effects of low-to-moderate $\mathrm{CO} 2$ concentrations on human decision-making performance. Environ. Health Perspect. 2012;120:16711677. https://doi.org/10.1289/ehp.1104789

Sebiany AM, Hafez AS, Salama KF, Sabra AA. Association between air pollutants and anthropometric measurements of boys in primary schools in Dammam, eastern Saudi Arabia. Journal of Family and Community Medicine. 2018; 25: 155-62. DOI: 10.4103/jfcm.JFCM_34_18

Soltani, N., Keshavarzi, B., Moore, F., Tavakol, T., Lahijanzadeh, A.R., Jaafarzadeh, N., Kermani, M. Ecological and human health hazards of heavy metals and polycyclic aromatic hydrocarbons (PAHs) in road dust of Isfahan metropolis, Iran. Sci. Total Environ. 2015; 505: 712-723.

Takigawa, T., Wang, B., Sakano, N., Wang, D., Ogino, K., \& Kishi, R. A longitudinal study of environmental risk factors for subjective symptoms associated with sick building syndrome in new dwellings. Sci. Total Environ. 2009; 407 (19): 5223-5228.

World Health Organization [WHO]. The physical school environment: an essential component of a health-promoting school. 2004. https://apps.who.int/iris/bitstream/handle/10665/42683/9241590645. pdf? sequence $=1 \&$ is Allowed $=\mathrm{y} \& u a=1$, (accessed November 22, 2019).

World Health Organization [WHO]. Handbook Indoor Radon: A Public Health Perspective. WHO Press, Geneva. 2009. https://www.who. int/ionizing_radiation/env/9789241547673/ en/, (accessed April, 5, 2020)
Zhang, L.L., Yang, L., Zhou, Q.Y., Zhang, X., Xing,W.L.,Wei, Y.J., Hu, M., Zhao, L.X., Akira, T., Hayakawa, K., et al.. Size distribution of particulate polycyclic aromatic hydrocarbons in fresh combustion smoke and ambient air: A review. Journal of Environmental Sciences. 2020; 88: 370-384.

Zhu, X., Yoshikawa, A., Qiu, L., Lu, Z., Lee, C., Ory, M. Healthy workplaces, active employees: A systematic literature review on impacts of workplace environments on employees' physical activity and sedentary behavior. Building and Environment. 2020; 168. https:// doi.org/10.1016/j.buildenv.2019.106455 


\section{تقيـم جـودة الهـواء الداخـلي في المنشـآت التعليمية في المملكـة العربية السـعودية: مراجعسة منهجية}

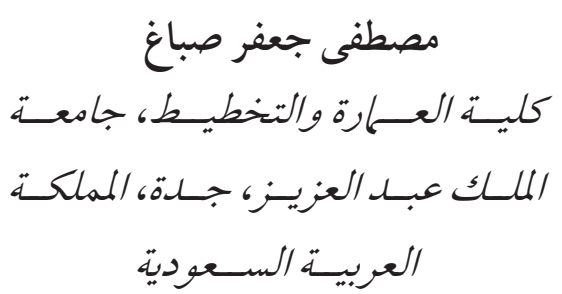

Mjsabbagh@kau.edu.sa

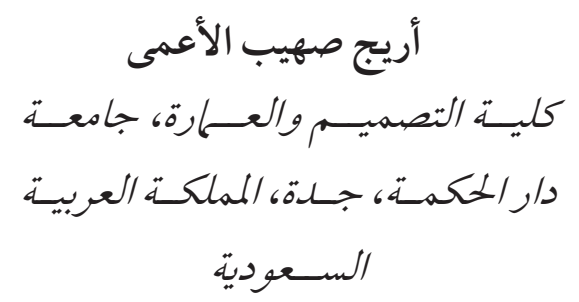

areejalama87@gmail.com

$$
\text { قدم للنشر في } 0 \text { / / / ع ع اهـ ؛ وقبل للنشر في / / / r ع ع اهـ. }
$$

ملخص البحث. تختلف تقييات جودة الهواء الداخلي (IAQ) التي يتم إجراؤها في الفصول الدراسية في المناطق الحارة الجافة؛ اختلافًا كبيرًا عن الحالات الموجودة في الدراسات العامة، بسبب الاختيلافات في السياق الاجتماعي و الثقافي، و الظروف المناخية، وتصميم المبنى و التشغيل ـ تهدف هذه الورقة البحثية إلى إنشاء مر اجعة

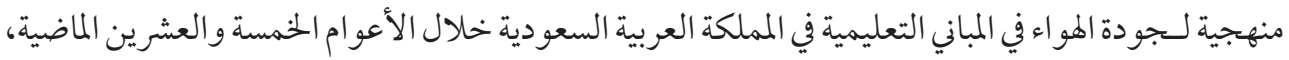
وتحديد مخاطر التلوث، والإشارة إلى التحسينات والثغرات. يغطي البحث مجموعة من مؤشرات جودة الهو اء،

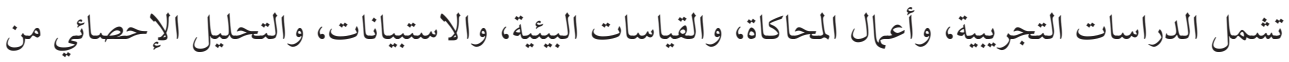
تخصصات متعددة لتقديم منظور عام شامل. هذه المراجعة تعد مهمة؛ لأن الدراسات في مثل هذا السياق عحدو دة من حيث العدد ومستوى التفاصيل . باستخدام PRISMA Model كمنهجية للبحث، تم العثور على V دراسة تتناسب مع معيار المراجعة؛ كان بعضها فريدًا من حيث المتغيرات التي تم فحصها. من بين

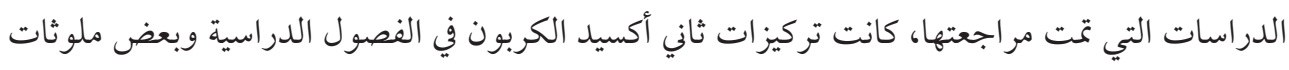
الهواء الداخلية المقاسة أعلى بكثير من القيم التي أوصت بها المعايير العالمية. كما ارتبطت المخاطر الصحية

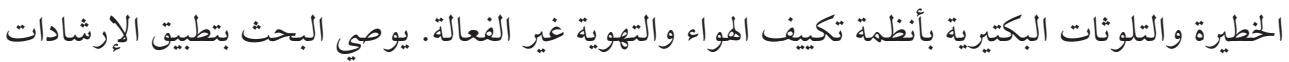

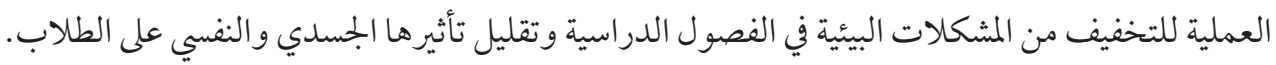

الكلمات المفتاحية: جودة الهواء الداخلي، ملوثات الهواء الداخلي، تركيز ثاني أكسيد الكربون، الجسييات الدقيقة، معادن ثقيلة، الر احة الحرارية، منشأة تعليمية. 